\title{
Harnessing of urease activity of Helicobacter pylori to induce self-destruction of the bacterium
}

\author{
M A Greig, W D Neithercut, M Hossack, K E L McColl
}

\begin{abstract}
Eradication of Helicobacter pylori with currently available antibacterial agents is unsatisfactory due to the risk of sideeffects and the emergence of resistance. The organism rapidly dies in vitro in the presence of urea at pH 6 . When incubated in citrate buffer (pH 6) plus urea $(10 \mathrm{mM})$ the five minute survival was $26 \%$ compared with $96 \%$ without urea and the survival progressively decreased with increasing urea concentrations, being only $9 \%$ in $50 \mathrm{mM}$ urea. The bactericidal effect depended on $\mathrm{pH}$ as the organism survived in citrate buffer (pH 7) plus urea ( $50 \mathrm{mM}$ ). The death of the organism at $\mathrm{pH} 6$ in the presence of urea was prevented by the addition of the competitive urease inhibitor hydroxyurea.
\end{abstract}

These findings indicate that destruction of the organism is mediated by its exceptionally high urease activity. Harnessing this enzyme to induce selfdestruction could provide a new approach to eradicating this common infection.

About $50 \%$ of the world's adult population are infected with Helicobacter pylori in their gastric antral mucosa, ${ }^{1}$ and there is now strong evidence that the organism is the single most important acquired factor in the pathogenesis of duodenal ulcers. More than $95 \%$ of patients with duodenal ulcers have the infection and eradicating it reduces the annual relapse rate from $84 \%$ to $21 \%{ }^{2}$ Unfortunately, the benefits of this new approach to ulcer treatment cannot be realised as no safe and effective antibacterial regimen has been discovered that is suitable for widespread eradication of the organism in such patients.

We present the results of experiments which show an entirely new approach to killing $H$ pylori. It entails harnessing the organism's exceptionally high urease activity to induce self-destruction. The phenomenon was noted by chance during in vitro studies of the role of the organism's urease activity in allowing the bacterium to survive in gastric acid. We found that $H$ pylori died rapidly when exposed to citrate buffer at $\mathrm{pH} 6$ in the presence of $50 \mathrm{mM}$ urea. This was confirmed using nine fresh clinical isolates obtained by culture of endoscopic antral biopsy specimens from patients with duodenal ulcers. The following experiments were performed to investigate this observation.

\section{Methods}

The basic experimental design consisted of measuring the survival of $\mathrm{H}$ pylori at a range of $\mathrm{pH}$ and the effect on this of varying the urea concentration of the media and adding the urease inhibitor hydroxyurea. In each experiment $1 \mathrm{ml}$ of a 72 hour broth culture suspension (brain-heart-infusion broth + $0.25 \%$ yeast extract $+10 \%$ horse serum) of $H$ pylor $i$ was added to $9 \mathrm{ml}$ of $0.2 \mathrm{M}$ citrate buffers or to isomolar unbuffered saline and incubated at $37^{\circ} \mathrm{C}$. After five minutes aliquots were removed for viable bacterial counts and where appropriate for measurement of ammonium concentrations. The $\mathrm{pH}$ was monitored using a combined glass electrode (Radiometer GK2802C).

Using the above protocol the following studies were performed:

(a) The survival of the organism was compared in citrate buffer ( $\mathrm{pH} 6$ ) and isomolar unbuffered saline both with and without 10 mM urea.

(b) The effect of varying the starting concentration of urea on survival in $\mathrm{pH} 6$ was assessed. (c) The effect of adding the competitive urease inhibitor hydroxyurea on the survival of $H$ pylori at $\mathrm{pH} 6$ in the presence of $10 \mathrm{mM}$ urea was examined.

(d) The effect of using citrate buffer $(\mathrm{pH} 7)$ compared with pH6 on the survival in $50 \mathrm{mM}$ urea was examined.

Survival was established using the method of Miles and Misra. ${ }^{3}$ Using a microtitre modification, serial 10 -fold dilutions of $20 \mu \mathrm{l}$ volumes were made in saline. Viable colony counts were performed on horse blood agar plates after 6 days' incubation at $37^{\circ} \mathrm{C}$ in a microaerophilic atmosphere (BBL CampyPak gas-generating system). Survival of the culture at a known time is expressed as a percentage of the starting innoculum calculated from the dilution of the viable colony count in the initial broth suspension. The aliquots removed for biochemical analysis were immediately filtered (Gelman Sciences, Acrodisc $0.2 \mu \mathrm{m}$ ) and stored at $-20^{\circ} \mathrm{C}$. The ammonium concentration was measured after 1 in 15 dilution in $0.2 \mathrm{M}$ phosphate buffer, $\mathrm{pH} 7 \cdot 4$, by an enzymatic method using the reductive amination of keto glutarate catalysed by glutamate dehydrogenase (Sigma Chemicals, UK) adapted for the Cobas Bio centrifugal-analyser (Roche, Welwyn Garden City, England). 
Figure 1 Survival of $H$ pylori in citrate buffer, $p H$ 6 , with different urea concentrations.

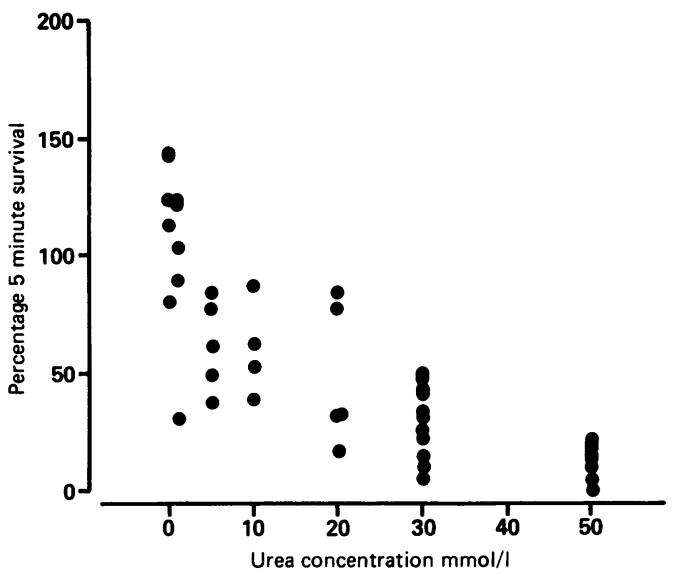

The experiments reported were performed using the National Collection of Tissue Cultures 11637 strain of $H$ pylori. Statistical analysis was performed using the MannWhitney U Test.

\section{Results}

The starting innoculum was determined separately for each experiment and was consistently $10^{5-6} \mathrm{cfu} / \mathrm{ml}$. The $\mathrm{pH}$ of the incubating solution remained constant in each of the experiments using citrate buffer. In the saline experiments with the urea the $\mathrm{pH}$ at the start ranged from $\mathrm{pH} 6 \cdot 26-6 \cdot 60$ and at five minutes had risen to $\mathrm{pH} 7 \cdot 04-7 \cdot 50$.

(a) EFFECT OF PRESENCE OF UREA ON SURVIVAL AT $\mathrm{PH} 6$

The median five minute survival in citrate buffer pH 6 was considerably reduced when urea $(10 \mathrm{mM})$ was present in the incubation solution (26\%, range $0-87$ with urea, $v 96 \%$, range $28-179$ without urea, $p<0.001)$. Similar results were obtained when fresh clinical isolates of $H$ pylor $i$ were tested, confirming that this is not purely a feature of the NCTC 11637 strain.

Median five minute survival in isomolar saline was not affected by the addition of 10 $\mathrm{mM}$ urea $(81 \%$ without urea compared with $77 \%$ with urea). The saline experiments were allowed to run for up to two and a half hours with no difference in survival.

(b) EFFECT OF INCREASING UREA CONCENTRATION ON SURVIVAL AT PH 6

The mean five minute survival at $\mathrm{pH} 6$ progres-

Figure 2 Effect of increasing concentrations of hydroxyurea on survival of $H$ pylori in citrate buffer, $\mathrm{pH} 6$, plus $10 \mathrm{mM}$ urea.

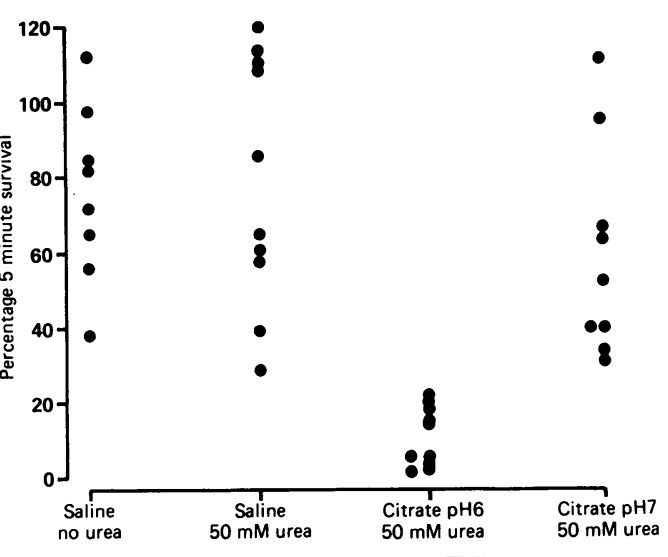

Figure 3 Survival at $p H 6$ versus $p H 7$ in presence of urea. For comparison, survival in isomolar saline with and without urea is shown.

sively decreased with increasing concentration of urea from $121 \%$ (range 69-148) in the absence of urea to only $9 \%$ (range $0-22$ ), with $50 \mathrm{mM}$ urea (fig 1).

(c) EFFECT OF ADDITION OF HYDROXYUREA ON SURVIVAL AT PH 6 IN PRESENCE OF UREA

The addition of hydroxyurea inhibited the killing effect of urea at $\mathrm{pH} 6$. This protective effect increased with increasing concentration of hydroxyurea (fig 2).

The median five minute ammonium concentration at $\mathrm{pH} 6$ in the presence of $10 \mathrm{mM}$ urea was $2.5 \mathrm{mmol} / 1$ (range 1.9-7.65) compared with $1.13 \mathrm{mmol} / 1$ (range $0.8-1.3$ ) in the blank incubation. When $10 \mathrm{mM}$ hydroxyurea was added the median five minute ammonium concentration was reduced to $1.29 \mathrm{mmol} / \mathrm{l}$ (range 1.03-1.53) ( $\mathrm{p}<0.001)$, indicating effective inhibition of urease enzyme activity.

\section{(d) COMPARISON OF SURVIVAL AT PH 6 VERSUS}

PH 7 IN PRESENCE OF UREA

When $H$ pylor $i$ was added to citrate buffer at $\mathrm{pH} 7$ plus urea $(50 \mathrm{mM})$ its mean five minute survival was $60 \%$ (range $31-112 \%$ ) and was similar to that observed in unbuffered saline with or without $50 \mathrm{mM}$ urea. The survival in buffer $\mathrm{pH} 6$ plus urea $(50 \mathrm{mM})$, however, was only $11 \%$ (range $2-22 \%$ ) (p $<0.001$ ), indicating that the killing effect is $\mathrm{pH}$ dependent (fig 3).

\section{Discussion}

We have shown that rapid death of $H$ pylori can be induced in vitro by changing the $\mathrm{pH}$ and urea concentration of its environment. Inhibition of the organism's urea activity with hydroxyurea prevents this happening. This

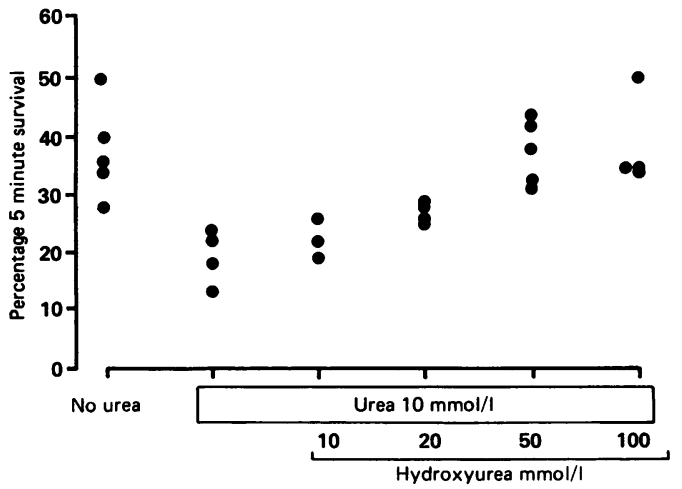
rapid death of $H$ pylori without the use of conventional antibacterial agents indicates suicidal destruction of the bacterium mediated by its urease activity. The use of isomolar saline shows that the effect is not merely a result of the changed osmolarity of the environment.

$H$ pylori is remarkable because of its high urease enzyme activity by which it converts urea to ammonia and carbon dioxide. ${ }^{4-6}$ This property is used in several tests for diagnosing the presence of the infection in man, and it has been suggested that the alkalinising effect of 
the ammonia may protect the organism from being destroyed by the acidic gastric juice.

In vitro studies have shown that the bacterium can survive at $\mathrm{pH} 2.6$ in the presence of urea but rapidly dies if no urea is available. ${ }^{7}$ Our experiments indicate that the organism's urease activity which aids survival at low pH can also result in rapid destruction of the bacterium at $\mathrm{pH} 6$ when ample substrate is available. We presume that death is due to the overproduction of ammonia resulting in irreversible metabolic damage.

This would concur with the observation that the activity of the enzyme is not suppressed by ammonium, ${ }^{5}$ indicating the absence of a protective feedback control mechanism.

To date, no satisfactory medical regimen has been discovered for eradicating $H$ pylori. To achieve eradication rates of $90 \%$ it is necessary to give two to four weeks triple treatment with tripotassium dicitrato-bismuthate, in combination with metronidazole, plus either amoxycillin or tetracycline. ${ }^{8}$ This complex combination treatment makes compliance difficult and is associated with side-effects, including potentially fatal pseudomembranous colitis.

The major problem with current treatment, however, is the tendency for the organism to develop resistance to metronidazole or tinidazole. Such resistance has been reported in $27 \%-84 \%$ of patients on first presentation with $H$ pylori infection and is associated with previous treatment with nitroimidazoles. ${ }^{9}$

Furthermore, in a significant proportion of patients, metronidazole resistance develops during the course of eradication treatment. ${ }^{9}$ The use of the current anti- $H$ pylori treatment is likely to result in the widespread development of resistant strains making eradication of this common infection even more difficult in future years. Consequently, there is a need for an alternative and more specific therapeutic approach.

Whether it will be possible to induce suicidal destruction of $H$ pylor $i$ in vivo by changing the $\mathrm{pH}$ and urea concentration of its immediate environment remains to be seen. The fact that the organism is confined to the surface of the gastric mucosa without any tissue invasion means that it is accessible to orally administered urea. We have shown that the intragastric administration of urea in patients with $H$ pylori results in a rapid increase of ammonia production, indicating that it gains ready access to the organism and its urease enzyme. ${ }^{10}$ The $\mathrm{pH}$ of gastric juice can also be changed readily with acid inhibitory agents, and it should be possible to produce a $\mathrm{pH}$ of 6 in the region of the organism. It is interesting to note that patients with increased gastric $\mathrm{pH}$ due to pernicious anaemia or duodenogastric alkaline reflux following gastric surgery have a low prevalence of $H$ pylori infection. ${ }^{11} 12$ Treatment with the powerful acid inhibitory agent omeprazole, which raises intragastric $\mathrm{pH}$ to near neutral values, has also been reported to clear $H$ pylori infection in some patients. ${ }^{1314}$ Omeprazole does not have any direct toxic or inhibitory effect on $H$ pylori in vitro. ${ }^{15}$ It is also of interest that patients with uraemia have been reported to have a lower prevalence of $H$ pylori infection. ${ }^{16}$

Our observations indicate a potential new approach to the eradication of this infection which could avoid the problems associated with current treatment.

1 Graham DY, Klein PD, Opekum AR, et al. Epidemiology of Campylobacter pylori infection: Ethnic considerations. Scand J Gastroenterol 1988;23(suppl 142):9-13.

2 Marshall BJ, Goodwin CS, Warren JR, et al. Prospective double-blind trial of duodenal ulcer relapse after eradication of Campylobacter pylori. Lancet 1988;ii:1438-42.

3 Miles AA, Misra SS. The estimation of the bactericidal power of the blood. J Hyg 1938;38:732-48.

4 Langenberg ML, Tytgat GNJ, Schipper MEI, Rietra PJGM, Zanen HC. Campylobacter-like organisms in the stomach of patients and healthy volunteers. Lancet 1984;i:1348.

5 Ferrero RL, Hazell SL, Lee A. The urease enzymes of Campylobacter pylori and a related bacterium. $J$ Med Microbiol 1988;27:33-40.

6 Mobley HLT, Cortesia MJ, Rosenthal LE, Jones BD. Characterisation of urease from Campylobacter pylori. $j$ Clin Microbiol 1988;26:831-6.

7 Tompkins DS, West AP. Campylobacter pylori acid and bile. J Clin Pathol 1987;40:1387.

8 Borody T, Cole P, Noonan S, et al. Long-term Campylobacter recurrence post-eradication. Gastroenterology 1988;94:A43.

9 Glupczynski Y, Burette A, Koster ED, et al. Metronidazole resistance in Helicobacter pylori. Lancet 1990;i:976-7.

10 Chittajallu RS, Neithercut WD, Macdonald AMI, McCol KEL. The effect of increasing Helicobacter pylori ammonia production by urea infusion on plasma gastrin concentrations. Gut (in press)

11 Flejou JF, Bahame P, Smith AC, Strockbrugger RW, Rose J, Price AB. Pernicious anaemia and Campylobacter-like organisms; is the gastric antrum resistant to colonisation? Gut 1989;30:60-4.

12 Offerhaus GJA, Rieu PNMA, Jansen JBMJ, Joosten HJM Lamers CBHW. Prospective comparative study of the influence of post-operative bile reflux on gastric mucosal influence of post-operative bile reflux on gastric mucosal
histology and Campylobacter pylori infection. Gut histology and

13 Mainquet P, Delmee M, Debongnie JC. Omeprazole Campylobacter pylori and duodenal ulcer. Lancet 1989;ii: 389-90.

14 Biasco G, Miglioli M, Barbara L, Corinaldesi R, DiFeho G. Omeprazole Helicobacter pylori gastritis and duodenal ulcer. Lancet 1989;i:1403.

15 Ghelani AM, Hale S, Coleman H, Radziwonik H, Robertson C, Atkinson M. Lack of in vitro activity of omeprazole against Campylobacter pylori. J Clin Pathol 1990;43: 171-3.

16 Shousha S, Keen C, Parkins RA. Gastric metaplasia and Campylobacter pylori infection of duodenum in patients
with chronic renal failure. J Clin Pathol 1989;42:348-51. 